\title{
A New Inscribed Assos Sarcophagus from Alexandreia Troas and the Collegium of Shipwrights
}

\author{
Tolga ÖZHAN* - Hüseyin YAMAN**
}

In October 2017, the inscribed sarcophagus discussed below was transferred to the former Çanakkale Archaeological Museum from the garden of a house in Kemalli, a village close to the ancient site of Alexandreia Troas, where it was used for a long time as a water trough. ${ }^{1}$ This is not an unusual find from Kemall. Several other inscribed artefacts, mostly funerary inscriptions, that had been moved from Alexandreia Troas to the village are documented in the epigraphic corpus of the ancient city of Alexandreia Troas. ${ }^{2}$

The inscribed sarcophagus is a typical half-fabricated example from Assos, the production of which began in the late second century AD (Figs. 1-3). ${ }^{3}$ Made of andesite, the most characteristic features that embellish Assos sarcophagi are a large panel positioned at the centre of the façade as well as two thin, smooth garlands with hanging pendants on either side of it. The façade is limited to a roughly outlined bucranium on the left and right sides. A disk adorns the semicircular space above the garlands. The short sides of the sarcophagus are occupied by a garland with a pendant, and, above it, a disk is depicted. The long back side of the sarcophagus has the same decorative order as the façade, with the exception of the central panel. Similar examples are not uncommon. One long side of the sarcophagus bears the decoration designated as "Form I" by Ward-Perkins in his drawings, while "Form II" adorns the other side, as it does on the sarcophagus introduced in this paper. ${ }^{4}$ Unlike the standard form of tabula ansata on Assos sarcophagi, which can be classified as a diverse group, the unusual form of these central panels on

* Dr. Öğretim Üyesi Tolga Özhan, Çanakkale Onsekiz Mart University, Faculty of Science and Letters, Department of Archaeology, 17100 Çanakkale (tolgaozhan@comu.edu.tr; https://orcid.org/0000-00027541-9864).

${ }^{* *}$ Dr. Öğretim Üyesi Hüseyin Yaman, Çanakkale Onsekiz Mart University, Faculty of Science and Letters, Department of Archaeology, 17100 Çanakkale (huseyinyaman@comu.edu.tr; https://orcid.org/00000003-1693-6500).

${ }^{1}$ On the short sides of our sarcophagus, there are holes which have most likely been punctured in the recent past to drain water from the vessel. An image of the back of this sarcophagus was previously been published in Arslan 2018 (515, fig. 21).

We would like to thank the Directorate of the new Çanakkale Troia Museum for their kind permission to publish this inscribed sarcophagus, Osman Çapalov for sharing his photos of the sarcophagus with us, and Christopher S. Lightfoot for reading the manuscript of this paper and sharing his views with us. Also, our thanks go to the anonymous peer-reviewers for their helpful additions and corrections.

${ }^{2}$ For list of funerary inscriptions found at Kemall, see Özhan - Yaman 2019, 114 fn. 1.

${ }^{3}$ On the reputation of Assos sarcophagi, also known as lapis sarcophagus, see Plin. nat. 2.97 (211); 36.27 (131). On the Assos sarcophagus, generally, see Koch - Sichtermann 1982, 515-519; Koch 1993, 171-173; Freydank 2000, 77-90; Arslan 2018.

${ }^{4}$ For drawings of these "forms", see Dodge - Ward-Perkins 1992, 141 fig. 133. 
Assos sarcophagi is intriguing. From a functional point of view, it is reasonable to describe this panel as a tabula. ${ }^{5}$ The large plain surface sometimes bears an inscription, but inscribed instances are small in number. ${ }^{6}$ When examined in terms of the shape of the panel, on the other hand, it can be suggested that the panel of "Form I" is a schematic representation of a funerary altar in a round or rectangular shape. Placed on the upper left and right sides of the flat-topped shaft, outwardly bulging components to which a garland is attached give the impression that it was the silhouetted profile of bucrania, while protrusions joined to the lower body form the base moulding (Fig. 2). Again, a funerary altar seems to have served as the model in the outline design of the panel of the "Form II". Unlike the former one, in this instance the bucrania were replaced by two short projecting quadrangles which probably represent a simple upper cornice (Fig. 1). It may be that the purpose of such symbolic representation on Assos sarcophagi refers back to an earlier practice indicating the use of a funerary altar together with the sarcophagus at Assos. Excavations in the western necropolis of the city by a team of Turkish and German archaeologists between 1989 and 1994 revealed that a grave stone (grabstein) inscribed with the name of the deceased was placed above a sarcophagus. This was a funerary practice observed from the midfifth century BC to the first half of the second century BC. ${ }^{7}$ J. Freydank argues that the smooth top surface of these blocks may have been used for offerings to the deceased in addition to its main function of marking the location of the sarcophagus by bearing the name of the deceased. ${ }^{8}$

It is difficult to trace whether there was a similar practice in Roman times because of the lack of a comprehensive study of Roman funerary practices in the Assos necropolis. Nevertheless, a few finds from the necropolis suggest that there may have been a connection between sarcophagus and funerary altar in the Roman imperial period at Assos. ${ }^{9}$ One example, considering the shape of the stone, is a cubic block decorated with geisipodes, possibly dating to the first century AD, bearing a posthumous honorary inscription for Heliophon, son of Zopyros, which would have served as a sarcophagus marker as well as funerary altar. ${ }^{10}$ Again in Assos, a few examples where a funerary altar was erected along with a sarcophagus were discovered during the first excavations conducted by J. T. Clarke and F. H. Bacon on behalf of the Archaeological Institute of

\footnotetext{
${ }^{5}$ For works defining this panel as a tabula or tabula ansata, see Koch - Sichtermann 1982, 518; Koch 1993, 172; Stefanidou-Tiveriou 2014, 285-288 nos. As 1-7 with plates 96-99; Nigdelis 2015, 227-229, no. 6, plate 46; Arslan 2018, 492; Özhan 2018, 52-53 nos. 4, 5.

${ }^{6}$ To our knowledge, instances with inscriptions that are coeval with the sarcophagus itself on the schematic funerary altars of Assos sarcophagi are as follows: Nikopolis: Papangeli 1984, 44-51 (cf. Dodge Ward-Perkins 1992, 58 fig. 48; Zachos 2015, 160); Ravenna: Dodge - Ward-Perkins 1992, 142-143, fig. 47 and 109; Thessaloniki: Stefanidou-Tiveriou 2014, 285-288 nos. As 3-7 with plates 98-99; Nigdelis 2015, 227-229, no. 6, plate 46. We know of only two inscribed instances from Assos, see Özhan 2018, 52-53 nos. 4-5. However, the inscriptions on the schematic altars from Assos apparently belong to a later date, i.e. Late Antiquity or Early Byzantine period. They may have been engraved during secondary use of the sarcophagi.

${ }^{7}$ Freydank 2000, 127-137 with several references to earlier excavation reports.

${ }^{8}$ Freydank 2000, 136.

${ }^{9}$ Referring to Naour 1980, 119 (non vidimus), Coulton $(2005,132)$ states that the practice of erecting a funerary altar beside a sarcophagus can be found in Tyriaion and Balboura.
}

${ }^{10}$ Özhan 2017 (BE 2018 368). 
America. Their report indicates that altars bearing an altar representation with two snakes feeding on it were commonly used in the necropolis in this period. ${ }^{11}$ One of these rectangular altars depicting snakes was apparently associated with a garland sarcophagus placed on a high monumental platform. Found lying on the pavement, this funerary altar was once positioned on the lower level of the platform in order to be visible in the centre of the garland sarcophagus. ${ }^{12}$ The excavators pointed out that this altar was attached to the platform at a later date. Even so, the case may be that perhaps a new authorized burial was made in the sarcophagus at a later date and this funerary altar was erected in the name of the deceased. Another rectangular funerary altar decorated with snakes associated with a group of sarcophagi was found in the western necropolis, placed on the podium of a vaulted chamber that housed three sarcophagi. ${ }^{13}$ This practice may have been abandoned for some reason, perhaps owing to its expense or the lack of space to erect more monumental elements, especially funerary altars, in the western necropolis, and a new hybrid style may have arisen in the late second century AD in which schematic altar forms were engraved on the sarcophagus itself. In this case, the symbolic altar on the sarcophagus was completely nonfunctional and solely honoured the memory of the deceased while imitating an earlier funerary practice at Assos. ${ }^{14}$

Interestingly, outside its main production centre, the Assos sarcophagus has rarely been found in other cities of the Troad or its immediate region. ${ }^{15}$ Notwithstanding its scarcity in the Troad, several are known from coastal cities in different parts of the Greco-Roman world; for example, in the eastern Mediterranean at Thessaloniki in Macedonia, Alexandreia in Egypt and Tyre in Syria, as well as Ravenna in Italy. ${ }^{16}$ The wide distribution of Assos sarcophagi in trade with overseas territories could be due to demand as a result of its peculiar reputation as consuming the flesh of the body buried in it. ${ }^{17}$ Another possible explanation is its cost, which may have been relatively lower than other known products on the market. This could have made it more affordable and accordingly, more attractive to the purchaser. ${ }^{18}$

\footnotetext{
${ }^{11}$ Clarke et al. 1902, 261, 289.

${ }^{12}$ Clarke et al. 1902, 260-261 no. 16 with figs. 1-2; 263 figs. 1-2, 271 fig. 1, 265, 267 (drawings).

${ }^{13}$ Clarke et al. 1902, 282-287 with figures and 271 with fig. 2.

${ }^{14}$ On the symbolic use of altars, see Coulton 2005, 129-130.

${ }^{15}$ A sarcophagus lid made of Assos (?) stone found at Nara Burnu (Abydos) is in Çanakkale Troia Museum (Inventory No: 7498). For other sarcophagi of Assos stone, see Tenedos: Tavukçu et al. 2004, 69, fig. 4 from Tenedos (without decoration); Kumkale: Koch - Sichtermann 1982, 517; Imbros: Ruhl 2018, 221225 F 155-F 160; Bakırköy near Gelibolu: Koçel-Erdem 2015, 446, fig. 3, who erroneously identified the sarcophagus as a product of Proconnesos.

${ }^{16}$ For a map showing the distribution of Assos sarcophagi, see Koch - Sichtermann 1982, 517 fig. 21. See also Dodge - Ward-Perkins 1992, 60 and 141-143 fig. 50; Koch 1993, 172; Arslan 2018, 498. For archaeometric studies on Assos sarcophagi, see Lazzarini 1994; Lazzarini - Visona 2009.

${ }^{17}$ Dodge - Ward-Perkins 1992, 35, 80, 119.

${ }^{18}$ Stefanidou-Tiveriou 2010, 155.
} 


\section{The New Sarcophagus}

The façade measures $2.10 \mathrm{~m}$ in length and the short sides are $0.94 \mathrm{~m}$ in width. The sarcophagus is $0.75 \mathrm{~m}$ high and the height of the letters varies between $0.05 \mathrm{~m}$ and $0.07 \mathrm{~m}$. Regardless of any specific registry, the inscription was roughly carved lengthwise on the façade of the sarcophagus.

Date: Third century AD.

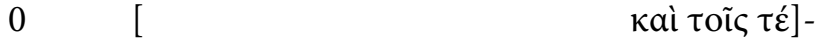

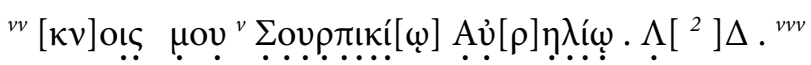

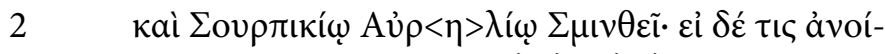

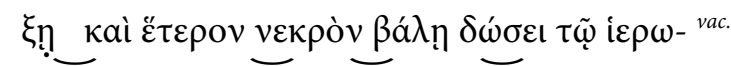

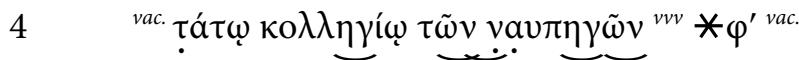

App. crit.: 1 The first surviving line is badly damaged at the top and therefore the upper half of most letters is missing. Nevertheless, the surviving lower halves allow us to restore a large part of this line (Figure 4). In a space large enough to contain two letters at the beginning of the line, some letter marks exist but they lack definite shape. In this line, the first legible letter is an omicron which is broken above. Next, only the vertical stroke of a letter is present. The following letter is square form sigma, the short vertical and horizontal stroke of which is visible on the stone. With two vertical strokes standing separately and indistint oblique stroke in the middle, the adjacent letter may be ny or my. Next, respectively, an omicron slightly broken above and the short vertical stroke of an upsilon with the lowest part of its $\mathrm{V}$ shape at the top are visible. These surviving letter marks and the highly formulaic structure of sarcophagus inscriptions lead us to con-

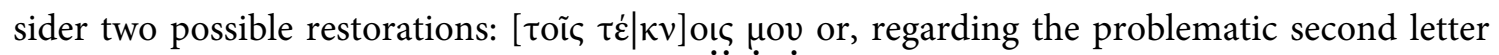

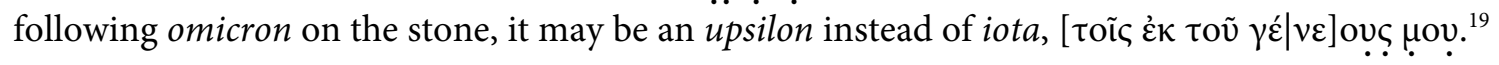
Referring to others who had the right to be buried in the sarcophagus, both suggestions make it

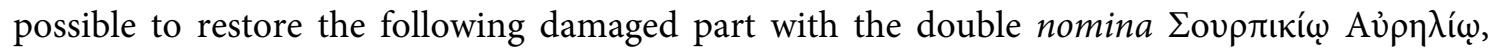

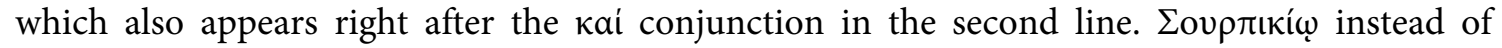
$\Sigma o v \lambda \pi$ เкí $\omega$; for the frequent change of lambda into rho, see Brixhe 1984, 44; Gignac 1976, 102 107. This addition can also be supported by the partially preserved letters, the identity of which can be determined particularly in comparison with the letter forms of the same double nomina in the second line (Fig. 4). Respectively, the surviving short vertical stroke and lowest horizontal stroke of a square form sigma, the remaining semicircle of an omicron broken above, the short vertical stroke of an upsilon, the vertical long stroke of a rho without any trace of its loop, both verticals of $p i$ lacking its horizontal stroke, an iota, the short vertical and the lower slanting stroke of a kappa and another iota almost perfect in condition are visible on the stone. From that point onwards, the letter marks on the stone become faint. Nevertheless, the identity of the majority of these letters is determinable under decent light. The space after the iota is large enough to fit an omega. However, the letter was completely defaced and only some vague marks are visible at this spot. Therefore, it is illegible. The following letter is an alpha, the left and right slanting strokes of which partially survive with its crossbar. Next, the vertical stroke of an upsi-

\footnotetext{
${ }^{19}$ Cf. I.Alexandreia Troas 85, 93, 94, 97, 99, 102, 122, 162 (?) and 129.
} 
lon and a small surviving part of the left stroke of its $\mathrm{V}$ shape at the top are visible. The following letter should be a rho, but it was badly damaged and there is no specific mark on the stone indicating that it is a rho. The lowest verticals of an eta and following this letter the inclining strokes of a lambda are all visible, but faint. Only a small part of the iota can be seen. The verticals of an omega with its inwardly slanting strokes are in comparatively good condition. As well as the collocation of two individuals bearing the same double nomina, taking into account the frequency

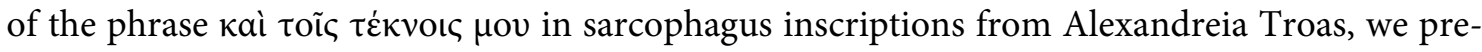

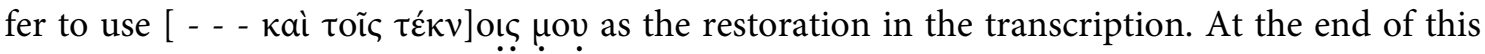
line, a cognomen in the dative follows the nomina but it is difficult to propose a name to restore it since in this part of the inscription only two separately standing letters can be seen, i.e., respectively, a lambda or an alpha and a delta, otherwise it is illegible. || $2 \mathrm{~A} Y \mathrm{P} \Lambda \mathrm{I} \Omega$ lapis || 3 When compared with other $n y$ letters e.g. in the second line, the form of the initial and the last $n y$ in the word NEKPON are unusual. It is likely that the mason erroneously engraved both $n y$ as my then converted them into $n y$ by elongating the oblique stroke (Figure 5) || 3-4 IЕРОГАТ $\Omega$ lapis I| $4 \mathrm{~N} \Delta$ ҮПНГ $\Omega \mathrm{N}$ lapis. Note that the form of the initial ligatured $n y$ is not conventional as it has a vertical right stroke slightly leaning to the right. The ligature of $n y$ with $n y$ is uncommon, e.g. see the example in I.Leukopetra 30 with a photograph on p. 297. Alpha following $n y$ was erroneously engraved as delta.

Translation: "[ - - and] for my children Sulpicius Aurelius [cognomen] and Sulpicius Aur $<$ e $>$ lius Smintheus. If anyone opens (the sarcophagus) and places another body (in it), he will give 500 denarii to the most sacred collegium of shipwrights."

Probably partially engraved on the rim of the missing lid, the beginning of the inscription should have borne a formulaic sentence including the name of the owner of the sarcophagus as well as a verb indicating its erection. ${ }^{20}$

Bearing a double nomina is a case that could occur on several occasions. For example, a slave would receive the nomen of two patrons after manumission or an adopted individual would append the nomen of the adoptive person to his own nomen, or, as is frequently attested, a maternal nomen could collocate with the paternal one. ${ }^{21}$ Another explanation that fits our example is that Aurelius may have been incorporated into the nomenclature as a second nomen with the declaration of Constitituo Antoniniana in AD 212. ${ }^{22}$ The lack of parental nomenclatures in the inscription, however, does not allow us to state more than possibilities in our case. This is the first epigraphic record of the nomen Sulpicius in Alexandreia Troas and no other individual bearing this nomen is known in the Troad. From immediate surroundings, one $\Sigma 0 \lambda \pi i \kappa ı$ ' is found on a very fragmentary inscription from the island of Imbros, listing mystai eusebeis. ${ }^{23}$ In this instance, however, it is not clear whether it was used as a personal name or nomen gentilicium. In

\footnotetext{
${ }^{20}$ To designate erecting a sarcophagus, $\tau i \theta \eta \mu$ is the most common verb used in the sarcophagus inscriptions of Alexandreia Troas, see I.Alexandreia Troas 83, 84, 85, 94, 97, 98, 101, 102, 109, 111A, 129; cf. Ricl 2000, 130.

${ }^{21}$ Salomies 1992, 61-63.

${ }^{22}$ Salomies 1992, 62.

${ }^{23}$ IG XII 8, 89. Cf. Cargill 1995, 395 no. 1165; Ruhl 2018, 235 F 186. For $\Sigma o \lambda \pi i ́ \kappa ı$ (Solpicius) instead

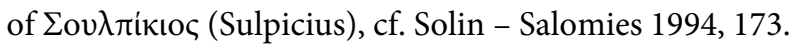


the neighbouring region of Mysia at Kyzikos, we encounter the name Lucius Sulpicius Apelles in an inscription recording prytanis-lists, dated to the reign of Hadrian. ${ }^{24}$ In Mysia, again, an alleged restoration of the nomen Sulpicius appears in a bilingual honorary inscription from Miletoupolis for Asper, son of Publicius, after the restoration of Domaszewski who, considering the rarity of the cognomen Asper, associated this Asper with a certain Sulpicius Asper, who was one of the participants in the conspiracy against Nero. ${ }^{25}$ However, this addition has not been accepted generally. ${ }^{26}$ Apart from above examples, this nomen is attested in the epigraphic inventory of various cities in Asia Minor, especially in the region of Ionia. ${ }^{27}$

Used as a cognomen of Sulpicius Aurelius in our inscription, Smintheus was the epithet of Apollo who was worshipped at Smintheion, an important oracle in the Troad that was attached to Alexandreia Troas in the Hellenistic period. ${ }^{28}$ Another Smintheus documented in a very fragmentary inscription from Smintheion must have been used as a cognomen as well. ${ }^{29}$ It seems that with the influence of the cult, Smintheus became a popular name in the Troad and its vicinity. ${ }^{30}$ Nevertheless, this name and its related derivatives are not restricted to this geography. The earliest example of Smintheus is known in the account of Enalos the Aeolian, told by Myrsilos of Lesbos, who fell in love with the daughter of Smintheus, one of the settlers on Lesbos, accompanying Euchelaos. ${ }^{31}$ In Lesbos again, a round altar of the Roman Imperial period which was discovered at Pyrgi near Mytilene records a dedication to Dionysos by an individual named

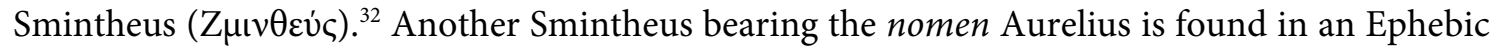
catalogue from Attica, dated to between AD 237/8 and 243/4. ${ }^{33}$ Further epigraphically attested derivatives are $\Sigma \mu \iota v \theta i a$ at Kyzikos in Mysia, $\Sigma \mu i v \theta ı \varsigma$ (?) at Mylasa in Caria, and $\Sigma \mu i v \theta ı \varsigma$ at Meg-

${ }^{24}$ Mordtmann 1881, 43 no. 2 (cf. IMT no. 1461).

${ }^{25}$ AE 1907 181; Domaszewski 1908, 7 (AE 1908 130); ILS III 9108; I.Miletoupolis 26; Kearsley 2001, 82 no. 111.

${ }^{26}$ For example, see I.Miletoupolis 26, the editor of which found it more acceptable to associate this Asper with that mentioned in I.Miletoupolis 25, who was honoured by the demos and the council of the ancient city of Miletoupolis.

${ }^{27}$ Ionia: I.Ephesos 1489, 1616; Knibbe 1981-1982, 147 no. 164; Engelmann - Knibbe 1989, 27 line 103;

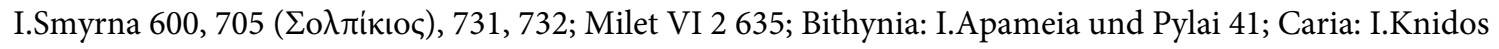
77, 89, 90467 (?); I.Stratonikeia 705; Reynolds 1982, 47; Galatia: Avcu 2016, 116-117 nos. 1-3; Lycia: IGR

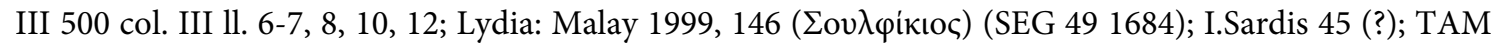
V 1 653; Phrygia: MAMA IV 143.

${ }^{28}$ On the incorporation of the ancient city of Hamaxitos as well as the sanctuary of Apollo Smintheus into the territory of Alexandreia Troas, see Bresson 2007, esp. 156. On the sanctuary of Apollo Smintheus, in general, see Cook 1973, 228-231; Özgünel 2012 and 2015.

${ }^{29}$ Özgünel - Kaplan 2009, 425 (SEG 59 1415).

${ }^{30}$ Sittig 1911, 47.

${ }^{31}$ FGrH 477 F 14 (cf. LGPN I s.v.).

${ }^{32}$ IG XII 2, 124 (cf. LGPN I s.v.).

${ }^{33}$ IG II $^{2} 2239$ line 242 (cf. LGPN II s.v.). 
ale polis in Arcadia, on Thasos and at Lindos on Rhodes where, also, according to Strabo (XIII.1. 48), a place called Sminthia exists. ${ }^{34}$

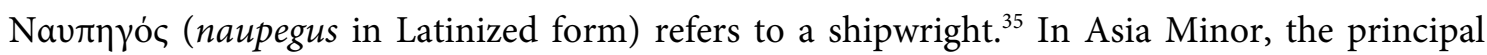
medium by which shipwrights found the opportunity to make themselves visible to the public was funerary inscriptions. A Hellenistic epitaph in Istanbul Archaeological Museum, the original find-place of which is unknown but probably originated from Byzantion, records the memory of a shipwright named Philippos, son of Zopyros. ${ }^{36}$ In addition, a fragmentary epitaph at Miletos attests to an anonymous shipwright. ${ }^{37}$ Two shipwrights named Ioannes and Pankratios, are known from a sarcophagus inscription at Korykos in Cilicia. ${ }^{38}$ Another shipwright from Korykos was Konon. ${ }^{39}$ One prominent instance of a naupegos is attested in a Latin inscription from Ephesos, dating to the Roman Imperial period, which informs us about Flavius Apollinarius, who was not just an ordinary naupegus but an expert at caulking in the classis Syriaca, i.e. naupegus aupiciarius (=oppiciarius). ${ }^{40}$ Additionally, examples of naupegoi are also known in other parts of the Greco-Roman world. For example, in an epitaph from Pantikapaion belonging to the early imperial period, we encounter a naupegos named Sisas. ${ }^{41}$ From the island of Cos, an attestation to naupegos comes from a fragmentary inscription dated to the third century AD, by which we are informed that a nonmilitary fleet and shipwrights (naupegoi) were the responsibil-

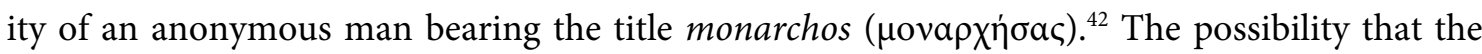
shipwrights working on the island of Cos may have constituted a professional association is implied by D. Bosnakis and K. Hallof. ${ }^{43}$ Another example of naupegos is found in the edict of Diocletian issued in AD 301, in which the daily wage of naupegos was determined according to their branch: 60 denarii for naupegos working on seagoing vessels and 50 denarii for naupegos working on river vessels. ${ }^{44}$ Unlike all these instances listed above, however, the Alexandreia Troas inscription is the first epigraphic evidence of a professional association of shipwrights in Alexan-

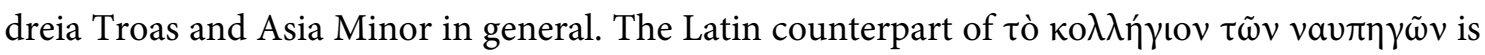
corpus fabrum navalium, the presence of which is epigraphically found at important harbour cities, as in the case of Portus, Ostia, Pisae, Arelate and Ravenna in the Roman west. ${ }^{45}$ Of these, especially the inscriptions concerning the associations of shipwrights at Ostia and Portus, i.e. cor-

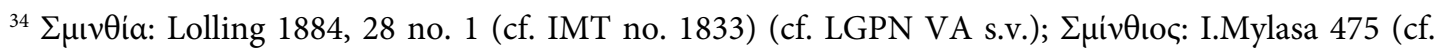
LGPN VA s.v.); $\Sigma \mu$ iv $\theta$ เc: LGPN I and IIIA s.v.

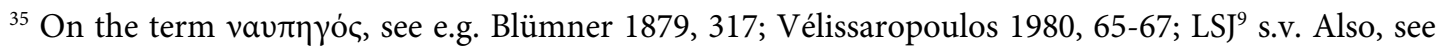
I.Byzantion 378, which is very informative.

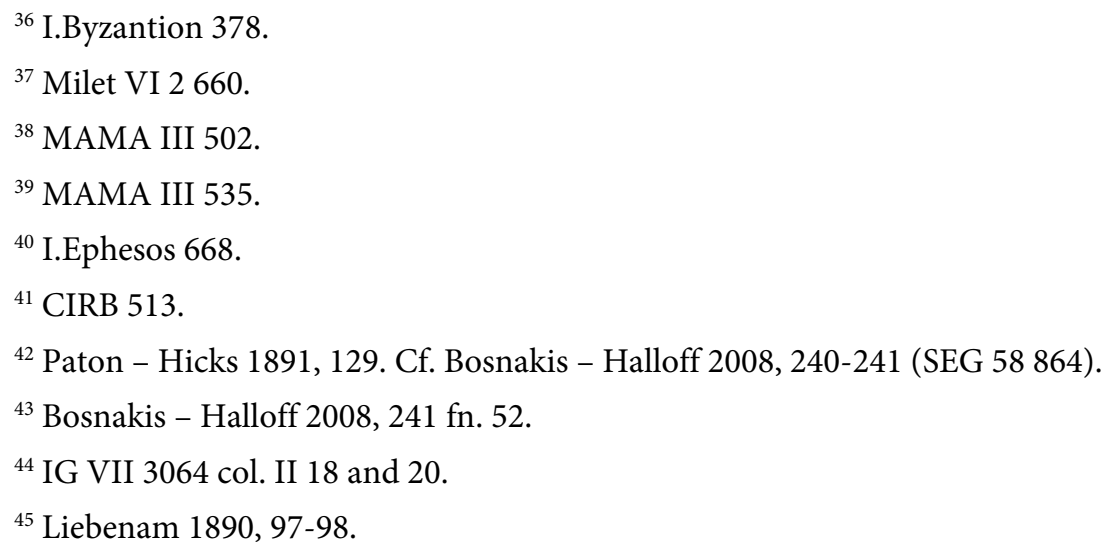


pus fabrum navalium Ostiensium and corpus fabrum navalium Portensium, provide us with sufficient information about these associations. ${ }^{46}$

D. Rohde highlights the fact that the active role of the corpus fabrum navalium at Ostia in the economy of the harbour city undeniably rendered the association conspicuous in society. ${ }^{47}$ Although we are not informed about the reputation of the association of shipwrights attested in the harbour cities mentioned above, it is manifest that these associations would have been significantly involved in the local economy. It is likely that the size of their contribution was partly related to the density of maritime traffic using the harbour. S. Feuser argues that the harbour of Alexandreia Troas, although medium-sized and not as large as the harbours of Ephesus and Portus, was a notable stop for vessels travelling between the Aegean and Black Sea and vice ver$s a$, but especially for those who were hindered from sailing by the prevailing northerly wind. ${ }^{48}$ Accordingly, the heavy traffic in the harbour may have brought potential customers to the collegium which, as well as fulfilling the requirements of local ship construction, would also have served visiting ships in need of repair. ${ }^{49} \mathrm{C}$. Bayburtluoğlu points out that the harbour of Alexandreia Troas offered enough space for the shelter of ships and also for their construction. ${ }^{50}$ However, there is no archaeological evidence actually pointing to the presence of a shipyard at Alexandreia Troas. ${ }^{51}$ Despite this deficiency, the narrative of the miracle performed by Bishop Silvanus, told by Socrates Scholasticus, confirms that in the early fifth century AD cargo ships big enough to transport large granite columns were built on the coast of the ancient city of Alexan-

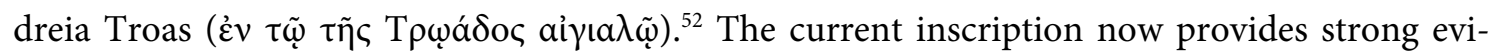
dence for the presence of a shipyard in or nearby the city in the third century AD. The inscription indicates that the shipwrights at Alexandreia Troas labelled their collegium with the superla-

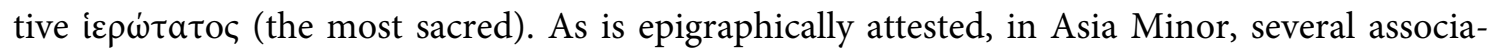

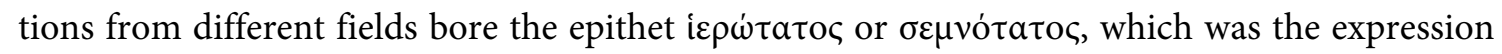
of the association's prestige in society. ${ }^{53}$ Apart from the collegium of shipwrights, no other

${ }^{46}$ Waltzing 1896, 77-78. On the association at Ostia, see Rohde 2012, 138-144, who gives at full list of the relevant inscriptions of the corpus fabrum navalium Ostiensium and corpus fabrum navalium Portensium on p. 138 fn. 340.

${ }^{47}$ Rohde 2012, 139.

${ }^{48}$ Feuser 2009, 128-129; Feuser 2011, 271.

${ }^{49}$ Cf. Rohde 2012, 138.

${ }^{50}$ Bayburtluoğlu 1976, 39 s.v. Alexandria Troas.

${ }^{51}$ In his brief writing on shipyards, Vitruvius (V.12.7) advises that the façade of shipyards should not be constructed facing south in order to prevent rot and damage from various pests.

${ }^{52}$ Sokr. VII.37. Cf. I.Alexandreia Troas p. 234-235. The timber for shipbuilding and components needing repair may have been obtained from the heavily-forested slopes of Mount Ida nearby, which was the main timber supplier for the region from early times; cf. Ellis-Evans 2019, 79-81.

${ }^{53}$ Cf. Dittmann-Schöne 2001, 16; Harland 2014, 440. For the associations bearing these epithets, see

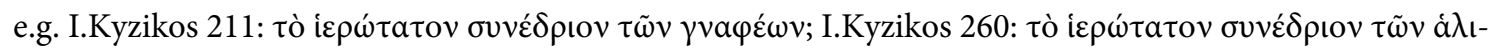

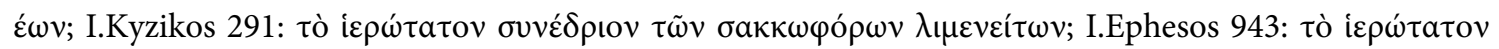

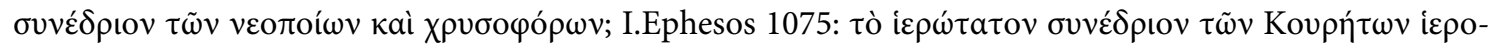

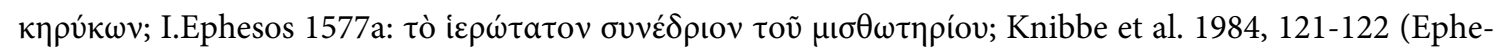

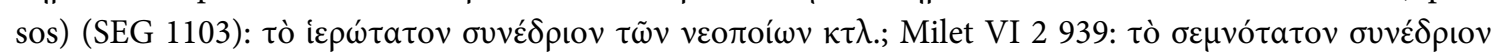


known professional association at Alexandreia Troas used this epithet, implying that the collegium of shipwrights had a superior reputation in the city in the third century AD. This was probably as a result of services rendered to foreign trading vessels anchoring in the harbour rather than meeting local demands and, accordingly, its significant involvement in the local economy.

It is not surprising, in fact, to see the occurrence of a Greek rendering of the Latin collegium in an inscription from a Roman colony, in our case Colonia Augusta Troadensis, or Romanized area. ${ }^{54}$ The loan of the term collegium in Greek is occasionally found in the inscriptions of Asia Minor. ${ }^{55}$

The anonymous owner of the sarcophagus in question in this paper may have been associated with the collegium of shipwrights, presumably as a naupegos himself. ${ }^{56}$ Designating an association or, in some cases, more than one association as the recipient of a fine in the event of violation of a grave or sarcophagus was a very common practice in Asia Minor. As attested in our inscription, the case is no different in Alexandreia Troas. In the ancient city of Alexandreia Troas, by means of sarcophagus inscriptions from the site, we also know that the guild of porters in the emporion, the guild of harbour-porters (?) and the club of coppersmiths (?) were mentioned as fine-receivers. ${ }^{57}$ In all these cases, the association was the sole authority granted to receive a monetary fine by the owner of the sarcophagus, except for the instance in I.Alexandreia Troas 153

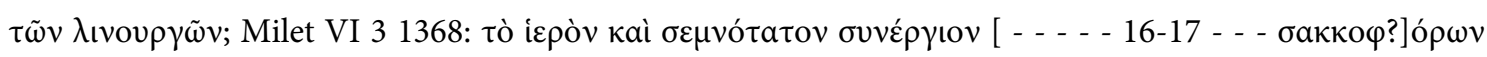

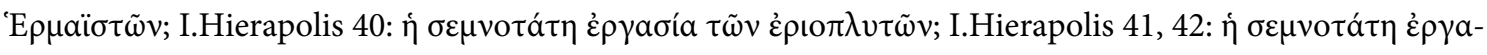

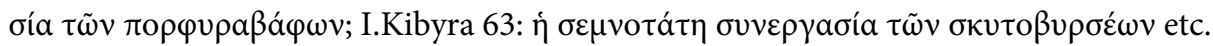

${ }^{54}$ See Poland 1909, 155; Mason 1974, 5, 61. For the dominant Latin character of Alexandreia Troas, see I.Alexandreia Troas p. 13.

${ }^{55}$ Clerc 1885, 127-128 Face B (cf. Nysa 2) (Nysa); I.Ephesos 4117 (Ephesos); TAM V 171 (Thermae Theseos); Bosch 1967, 188 no. 149 (Galatia); Laminger-Pascher 1992, 73 no. 69 (Lycaonia); Studia Pontica III 29 (Therma Phazimoniton). For instances from Macedonia, see SEG 39597 (Kassandreia); Robinson 1938, 61 no. 15 (Kassandreia); SEG 47954 (Stobi).

${ }^{56}$ In general, sarcophagus inscriptions in Asia Minor bearing a fine which was to be paid to professional association(s) are silent about the profession of the owner of the sarcophagus and the affiliation between the owner and the designated association. The only relevant instance from Asia Minor we were able to find is I.Ephesos 2212 in which both the profession of the grave's owner was recorded and a pertinent association was designated as the fine receiver. The owner of the sarcophagus was Marcus Antonius Hermeias who was a silversmith (argyrokopos) and a temple-warden (neopoios). He indicated a fine of 1000

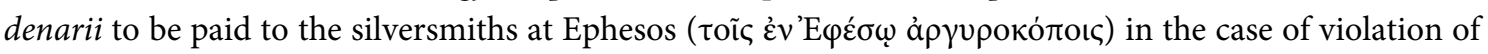
his sarcophagus. Moreover, he entrusted the care of his grave to the same synedrion. In another funerary inscription from Ephesos (I.Ephesos 3216), although there is no mention of a designated fine receiver, we are informed that the owner of the sarcophagus Pompeius Euprosdektos, who was a grain-measurer (prometres), relied upon the grain-measurers at Ephesos to control the fulfillment of the responsibilities for the commemoration rituals. On the funeral activities of professional associations, in general, see van Nijf 1997, 31-69, esp. 55-60; Dittmann-Schöne 2001, esp. 85-91.

${ }^{57}$ The guild of porters in the emporion: I.Alexandreia Troas 151, 152; the guild of harbour-porters: I.Alexandreia Troas 153 (The find-place of this inscription is Alexandreia Troas or Smyrna); The club of coppersmiths: I.Alexandreia Troas $122=$ I.Ilion 171 (cf. Harland 2014, 76. The find-place of this inscription is problematic; it may belong to Ilion or Alexandreia Troas.). 
where the polis of Alexandreia Troas was named along with the guild of harbour-porters. As for the amount of the fine, 500 denarii were a relatively small sum compared to other funerary fines recorded on sarcophagus inscriptions at Alexandreia Troas. For example, in two inscriptions associated with the guild of porters in the emporion, 2500 denarii were designated as the funerary fine, while in I.Alexandreia Troas 122, the potential offender was obliged to pay 1500 denarii to the club of coppersmiths. ${ }^{58}$ Another funerary fine from Alexandreia Troas more similar to the one mentioned in our inscription comes from a sarcophagus inscription in which 250 denarii would have to be paid to the guild of harbour porters and 1500 denarii to the polis of Alexandreia Troas. In general, 500 denarii were apparently one of the most frequently-mentioned fines in the sarcophagus inscriptions of Asia Minor; and in most cases, the designated recipient was the fiscus, tameion, polis or demos.

\section{Bibliography}

$\mathrm{AE}$

Reynolds 1982

Arslan 2018

Avcu 2016

Bayburtluoğlu 1976

$\mathrm{BE}$

Blümner 1879

Bosch 1967

Bosnakis - Halloff 2008

Bresson 2007

Brixhe 1984

Cargill 1995
L'Année épigraphique.

J. Reynolds, Aphrodisias and Rome, London 1982.

N. Arslan, Assos'da Lahit Üretimi ve İhracat1, in: XVII. Türk Tarih Kongresi, 15-17 Eylül 2014, Kongreye Sunulan Bildiriler I. Cilt: Eski Anadolu Uygarlıkları, Ankara 2018, 489-515.

F. Avcu, Nallıhan Çevresinden Yeni Yazıtlar: Sulpicii Ailesi, in: B. Takmer et al. (eds.), Vir Doctus Anatolicus. Sencer Şahin Anısına Yazılar, İstanbul 2016, 116-121.

C. Bayburtluoğlu, Alexandria Troas, in: R. Stillwell (ed.) The Princeton Encyclopedia of Classical Sites, Princeton 1976, 39.

Bulletin Épigraphique in Revue des Études Grecques.

H. Blümner, Technologie und Terminologie der Gewerbe und Künste bei Griechen und Römern II, Leipzig 1879.

E. Bosch, Quellen Zur Geschichte der Stadt Ankara im Altertum, Ankara 1967.

D. Bosnakis - K. Halloff, Alte und neue Inschriften aus Kos III, Chiron 38, 2008, 205-242.

A. Bresson, Hamaxitos en Troade, in: J. Dalaison (ed.), Espaces et pouvoirs dans l'Antiquité de l'Anatolie à la Gaule. Hommages à Bernard Rémy, Grebonle 2007, 139-158.

C. Brixhe, Essai sur le grec anatolien au début de notre ère, Nancy 1984.

J. Cargill, Athenian Settlements of the fourth century B.C., Leiden-New York-Köln 1995.

${ }^{58}$ According to the restoration of Cook $(1973,67 \mathrm{fn} .3)$, the amount of the fine payable to the club of coppersmiths was 2500 denarii but according to I.Ilion 171 it was 500 denarii. We prefer to use the text in I.Alexandreia Troas 122 in which the amount is 1500 denarii. 
CIRB

Clarke et al. 1902

Clerc 1885

Cook 1973

Coulton 2005

Dittmann-Schöne 2001

Dodge - Ward-Perkins 1992

Domaszewski 1908

Ellis-Evans 2019

Engelmann - Knibbe 1989

Feuser 2009

Feuser 2011

FGrH

Freydank 2000

Gignac 1976

Harland 2014

I.Alexandreia Troas

I.Apameia und Pylai
Corpus Inscriptionum Regni Bosporani $=$ Korpus Bosproskich Nadpisej, Leningrad 1965.

J. T. Clarke - F. H. Bacon - R. Koldewey, Investigations at Assos. Drawings and photographs of the buildings and objects discovered during the excavation of 1881-1882-1883, LondonCambridge-Leipzig 1902.

M. A. Clerc, Inscription de Nysa, BCH 9, 1885, 124-131.

J. M. Cook, The Troad. An Archaeological and Topographical Study, Oxford 1973.

J. J. Coulton, Pedestals as 'altars' in Roman Asia Minor, Anatolian Studies 55, 2005, 127-157.

I. Dittmann-Schöne, Die Berufsvereine in den Städten des kaiserzeitlichen Kleinasiens, Regensburg 2001.

H. Dodge - J. B. Ward-Perkins (eds.), Marble in Antiquity. Collected Papers of J. B. Ward-Perkins, London 1992.

A. Domaszweski, Kleine Beiträge zur Kaisergeschichte, Philologus 67, 1908, 1-11.

A. Ellis-Evans, The Kingdom of Priam. Lesbos and the Troad between Anatolia and the Aegean, Oxford 2019.

H. Engelmann - D. Knibbe, Das Zollgesetz der Provinz Asia. Eine neue Inschrift aus Ephesos (Epigraphica Anatolica 14), Bonn 1989.

S. Feuser, Der Hafen von Alexandria Troas (AMS 63), Bonn 2009.

S. Feuser, The Roman Harbour of Alexandria Troas, Turkey, The International Journal of Nautical Archaeology 40.2, 2010, 256273.

F. Jacoby, Fragmente der griechischen Historiker I-III, Leiden 1923-1958.

J. Freydank, Die Westtor-Nekropole von Assos in klassischer und hellenistischer Zeit, Unpublished PhD Thesis, Universität Mannheim, Mannheim 2000.

F. T. Gignac, A Grammar of the Greek and Roman Papyri of the Roman Byzantine Periods I. Phonology, Milan 1976.

P. A. Harland, Greco-Roman Associations: Texts, Translations, and Commentary. II. North Coast of the Black Sea, Asia Minor, Berlin 2014.

M. Ricl (ed.), The Inscriptions of Alexandreia Troas (IGSK 53), Bonn 1997.

T. Corsten (ed.), Die Inschriften von Apameia (Bithynien) und Pylai (IGSK 32), Bonn 1987. 
I.Byzantion

I.Ephesos

IG

IGR

I.Hierapolis

I.Ilion

I.Kibyra

I.Knidos

I.Kyzikos

I.Leukopetra

ILS

I.Miletoupolis

IMT

I.Mylasa

I.Sardis

I.Smyrna

I.Stratonikeia

Kearsley 2001
A. Łajtar (ed.), Die Inschriften von Byzantion (IGSK 58), Bonn 2000.

H. Wankel et al. (eds.), Die Inschriften von Ephesos I-VII (IGSK 11-17), Bonn 1979-1981.

Inscriptiones Graecae.

Inscriptiones Graecae ad res Romanas pertinentes I-IV, Paris 1901-1927.

W. Judeich (ed.), 'Inschriften', in: C. Humann et al. (eds.), Altertümer von Hierapolis (Jahrbuch des Kaiserlich deutschen Archäologischen Instituts 4), Berlin 1898, 67-202.

P. Frisch (ed.), Die Inschriften von Ilion (IGSK 3), Bonn 1975.

T. Corsten, Die Inschriften von Kibyra. Teil I: Die Inschriften der Stadt und ihrer näheren Umgebung (IGSK 60), Bonn 2002.

W. Blümel (ed.), Die Inschriften von Knidos I (IGSK 41), Bonn 1992.

E. Schwertheim (ed.), Die Inschriften von Kyzikos und Umgebung, Teil I: Grabtexte (IGSK 18), Bonn 1980.

P. M. Petsas et al. (eds.), Inscriptions du sanctuaire de la Mère des Dieux autochthone de Leukopétra (Macédoine), Athens 2000.

H. Dessau (ed.), Inscriptiones Latinae Selectae I-III, Berlin 18921916.

E. Schwertheim (ed.), Die Inschriften von Kyzikos und Umgebung. Teil II: Miletupolis. Inschriften und Denkmäler (IGSK 26), Bonn 1983.

Inschriften Mysia \& Troas [IMT], M. Barth - J. Stauber - L. Wenger Institut. Universität München. Version of 25.8.1993 (Ibycus). Packard Humanities Institute CD \#7, 1996. - Mysia, «Kyzikene, Kapu Dağ», nos. 1401-1856.

W. Blümel (ed.), Die Inschriften von Mylasa, I. Inschriften der Stadt (IGSK 34); II. Inschriften aus der Umgebung der Stadt (IGSK 35), Bonn 1988.

W. H. Buckler - D. M. Robinson (eds.), Greek and Latin Inscriptions (Sardis VII), Leiden 1932.

G. Petzl (ed.), Die Inschriften von Smyrna I-II 1/2 (IGSK 23-24 1/2), Bonn 1982-1990.

M. Ç. Şahin (ed.), Die Inschriften von Stratonikeia I/II (IGSK 2122 1/2), Bonn 1981-1990.

R. A. Kearsley (ed.), Greeks and Romans in Imperial Asia. Mixed Language Inscriptions and Linguistic Evidence for Cultural Interaction until the End of AD III (IGSK 59), Bonn 2001. 
Knibbe 1981-1982

Knibbe et al. 1984

Koch 1993

Koch - Sichtermann 1982

Koçel-Erdem 2015

Laminger-Pascher 1992

Lazzarini 1994

Lazzarini - Visona 2009

LGPN I

LGPN II

LGPN IIIA

LGPN VA

Liebenam 1890

Lolling 1884

$\mathrm{LSJ}^{9}$

Malay 1999
D. Knibbe, Neue Inschriften aus Ephesos VIII, JÖAI 53, 19811982, 87-150.

D. Knibbe - H. Engelmann - B. İplikçioğlu, Inschriften aus Ephesos IX, JÖAI 54, 1984, 161-238.

G. Koch, Sarkophage der Römischen Kaiserzeit, Darmstadt 1993.

G. Koch - H. Sichtermann, Römische Sarkophage, München 1982.

Z. Koçel-Erdem, Tekirdağ Merkez ve Şarköy İlçeleri ile Çanakkale Gelibolu Yarımadası (Trakya Khersonesos'u) 2014 Yılı Çalışmaları, AST 33.2, 2015, 443-462.

G. Laminger-Pascher, Die kaiserzeitlichen Inschriften Lykaoniens 1. Der Süden, Wien 1992.

L. Lazzarini, Lapis Sarcophagus: An Historical and Scientific Note, in: Conservazione del Patrimonio Culturale, contributi del Centro Linceo Interdisciplinare "Beniamino Segre" 88, 1994, 103 116.

L. Lazzarini - D. Visona, Lapis Sarcophagus and the Provenance of its Mediterranean Sarcophagi, in: P. Jockey (ed.), Leukos Lithos, Marbres et autres roches de la Méditerranée antique: études interdisciplinaires Actes du VIIIe Colloque International de l'Asamosia, Aix-en-Provence 12-18 juin 2006, Paris 2009, 369388.

P. M. Fraser - E. Matthews (eds.), A Lexicon of Greek Personal Names, I: The Aegean Islands, Cyprus, Cyrenaica, Oxford 1987.

J. Osborne - S. G. Byrne (eds.), A Lexicon of Greek Personal Names, II: Attica, Oxford 1994.

P. M. Fraser - E. Matthews (eds.), A Lexicon of Greek Personal Names, IIIA: The Peloponnese, Western Greece, Sicily and Magna Graecia, Oxford 1997.

T. Corsten (ed.), A Lexicon of Greek Personal Names, VA: Coastal Asia Minor: Pontos to Ionia, Oxford 2010.

W. Liebenam, Zur Geschichte und Organisation des Römischen Vereinswesens, Leipzig 1890.

H. G. Lolling, Inschriften aus den Küstenstädten des Hellespontos und der Propontis, Ath.Mit. 9, 1884, 15-35.

H. G. Liddell - R. Scott - H. S. Jones, A Greek-English Lexicon. With a revised supplement, Oxford 1996.

H. Malay, Researches in Lydia, Mysia and Aiolis (ETAM 23), Wien 1999.

MAMA
Monumenta Asiae Minoris Antiqua I-X, London 1928-1993. 
Mason 1974

Milet VI 2

Milet VI 3

Mordtmann 1881

Naour 1980

Nigdelis 2015

Nysa

Özgünel 2012

Özgünel 2015

Özgünel - Kaplan 2009

Özhan 2017

Özhan 2018

Özhan - Yaman 2019

Papangeli 1984

Paton - Hicks 1891

Poland 1909

Ricl 2000
H. G. Mason, Greek Terms for Roman Institutions. A Lexicon and Analysis, Toronto 1974.

P. Hermann (ed.), Inschriften von Milet, Teil 2: Inschriften n. 407-1019, Berlin-New York 1998.

P. Hermann - W. Günther - N. Ehrhardt (eds.), Inschriften von Milet, Teil 3: Inschriften n. 1020-1580, Berlin-New York 2006.

J. H. Mordtmann, Zur Epigraphik von Kyzikos, Ath.Mitt. 6, 1881, 40-55 and 120-131.

C. Naour, Tyriaion en Cabalide, épigraphie, et géographie historique, Zutphen 1980.

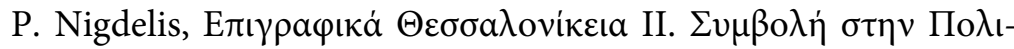

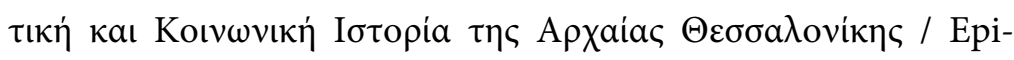
graphica Thessalonikeia II. Contribution to the Political and Social History of Ancient Thessaloniki, Thessaloniki 2015.

D. F. McCabe, Nysa Inscriptions. Texts and List. «The Princeton Project on the Inscriptions of Anatolia», The Institute for Advanced Study, Princeton (1991). Packard Humanities Institute CD \#7, 1996. - Includes (Nysa): F. B. Poljakov. Die Inschriften von Tralleis und Nysa. Teil I: Die Inschriften von Tralleis. «Inschriften griechischer Städte aus Kleinasien», 36,1. Bonn 1989.

C. Özgünel, Apollon Smintheus Tapınağı ve Homeros, in: O. Bingöl - A. Öztan - H. Taşkıran (eds.), Dil ve Tarih-Coğrafya Fakültesi 75. Yıl Armağanı. Arkeoloji Bölümü Tarihçesi ve Kazıları (1936-2011), Ankara 2010, 475-488.

A. C. Özgünel, Smintheion. In Search of Apollo Smintheus, İstanbul 2015.

A. C. Özgünel - D. Kaplan, 2007 Yllı Gülpınar/Smintheion Kazı Çalışmaları (28. Yıl), KST 30.4, 2009, 409-432.

T. Özhan, A New Honorary Inscription from Assos, Archivum Anatolicum 11.2, 2017, 71-76.

T. Özhan, Late Antique and Early Byzantine Era Inscriptions at Assos, Tekmeria 14, 2018, 47-68.

T. Özhan - H. Yaman, A New Sarcophagus Inscription from Alexandreia Troas, Anadolu/Anatolia 45, 2019, 113-124.

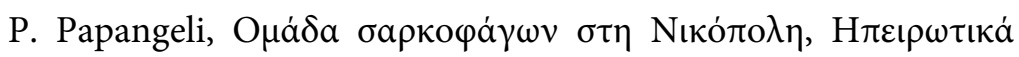
Xрovıкá 26, 1984, 43-70.

W. R. Paton - E. L. Hicks, The Inscriptions of Cos, Oxford 1891.

F. Poland, Geschichte des griechischen Vereinswesens, Leipzig 1909.

M. Ricl, Two New Inscriptions from Alexandreia Troas, Tekmeria 5, 2000, 127-132. 
Robinson 1938

Rohde 2012

Ruhl 2018

Salomies 1992

Sittig 1911

Solin - Salomies 1994

Stefanidou-Tiveriou 2010

Stefanidou-Tiveriou 2014

Studia Pontica III

\section{TAM}

Tavukçu et al. 2004

van Nijf 1997

Vélissaropoulos 1980

Waltzing 1896

Zachos 2015
D. M. Robinson, Inscriptions from Macedonia, 1938, TAPhA 69, 1938, 43-76.

D. Rohde, Zwischen Individuum und Stadtgemeinde. Die Integration von collegia in Hafenstädten, Berlin 2012.

B. Ruhl, Imbros. Archäologie einer nordostägäischen Insel, Marburg 2018.

O. Salomies, Adoptive and Polyonymous Nomenclature in the Roman Empire, Helsinki 1992.

E. Sittig, De Graecorum Nominibus Theophoris, Halle 1911.

H. Solin - O. Salomies, Repertorium nominum gentilium et cognominum Latinorum, Hildesheim-Zürich-New York ${ }^{2} 1994$.

T. Stefanidou-Tiveriou, Social Status and Family Origin in the Sarcophagi of Thessalonikē, in: L. Nasrallah - Ch. Bakirtzis - S. J. Friesen (eds.), From Roman to Early Christian Thessalonike, Studies in Religion and Archaeology, Harvard Theological Studies 64, Cambridge/Mass., 2010, 151-188.

T. Stefanidou-Tiveriou, Die lokalen Sarkophage aus Thessaloniki, Wiesbaden 2014.

J. G. C. Anderson - F. Cumont - H. Grégoire (eds.), Recueil des inscriptions grecques et latines du Pont et de l'Arménie (Studia Pontica III), Brussels 1910.

Tituli Asiae Minoris I-V.3, Vienna 1901-2007.

A. Y. Tavukçu - C. Başaran - Z. A. Tavukçu - E. Küçükefe, Bozcaada-Tenedos Araştırmaları 2002, AST 21/2, 2004, 67-76.

O. M. van Nijf, The Civic World of Professional Associations in the Roman East, Amsterdam 1997.

J. Vélissaropoulos, Les Nauclères grecs: Recherches sur les institutions maritimes eb Grèce et dans l'Orient hellénisé, Geneve, Paris 1980.

J.-P. Waltzing, Étude historique sur les corporations professionnelles chez les Romains, depuis les origines jusqu'à la chute de l'Empire d'Occident II, Bruxelles 1896.

K. L. Zachos, An Archaeological Guide to Nicopolis. Rambling through the historical, sacred and civic landscape, Athens 2015. 


\section{Aleksandreia Troas'tan Yazıtlı Yeni Bir Assos Lahdi ve Tersane İşçileri Derneği Öz}

Makalede yakın zamanda Aleksandreia Troas yakınlarındaki Kemallı Köyü’nde bulunmuş yazıtlı bir Assos lahdi tanıtılmaktadır. Yazarlar, Assos lahitlerinin her iki uzun yüzünde bulunan ve şekilleri itibariyle dikkat uyandıran geniş orta panelin aslında dikdörtgen veya silindirik gömü sunaklarının lahitler üzerine işlenmiş şematik bir tasviri olabileceğini ileri sürmektedir. Buna bağlı olarak, mezar sunaklarının lahit üzerine betimlenmesinin Assos nekropolisinde lahitle birlikte bir gömü sunağı dikme geleneğinin yeni bir melez biçemi olabileceği varsayılmaktadır. Roma İmparatorluğu'nun batısında birkaç önemli liman şehrinde faaliyet gösterdiği bilinen tersane iş̧̧ileri derneğinin Aleksandria Troas ve Asia Minor'daki varlığı, MS 3. yüzyıla tarihlenen bu yazıtla ilk defa epigrafik olarak belgelenmektedir. Derneği tanımlamak için kullanılan

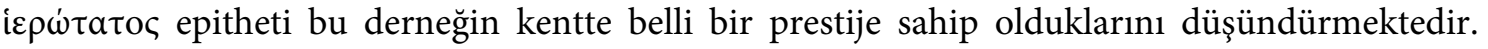
Lahdi hazırlatan kişinin bu dernekle bir bağlantısının olması muhtemeldir. Belki, o da bir tersane işçisiydi. Yazıtın tercümesi şöyledir: "[- - ve] evlatlarım Sulpicius Aurelius [cognomen] ve Sulpicius Aurelius Smintheus için [- - ] eğer biri (lahdi) açarsa ve (içerisine) başka bir ceset koyarsa son derece kutsal tersane işçileri derneğine 500 denar verecek".

Anahtar Sözcükler: Aleksandreia Troas, Assos lahdi, tabula, mezar sunağı, lahit yazıtı, dernek, collegium, tersane işçisi, naupegos.

\section{A New Inscribed Assos Sarcophagus from Alexandreia Troas and The Collegium of Shipwrights}

\section{Abstract}

This paper presents a new inscribed Assos-type sarcophagus found recently in Kemall, a village located a few kilometres east of the ancient city of Alexandreia Troas. A characteristic feature of the general decoration of Assos-type sarcophagi is the attention-grabbing shape of the sizeable central panel positioned on each of the long sides of the sarcophagus. It is proposed that these large central panels may have been schematic representations of rectangular or round funerary altars. Accordingly, the depiction of the funerary altar on the sarcophagus is considered to be a new hybrid style of the practice in the necropolis of Assos of erecting a funerary altar along with the sarcophagus. With this sarcophagus inscription dating to the third century AD, the presence of a professional association of shipwrights, which is known to have existed in a number of important harbour cities in the western part of the Roman Empire, is attested for the first time in

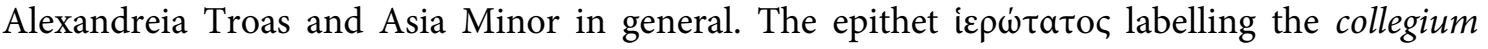
suggests that the association may have had a privileged position in the ancient city. The anonymous owner of the sarcophagus may have been associated with the collegium of shipwrights at Alexandreia Troas and, presumably, he was a shipwright.

Keywords: Alexandreia Troas, Assos sarcophagus, tabula, funerary altar, sarcophagus inscription, association, collegium, shipwright, naupegos. 


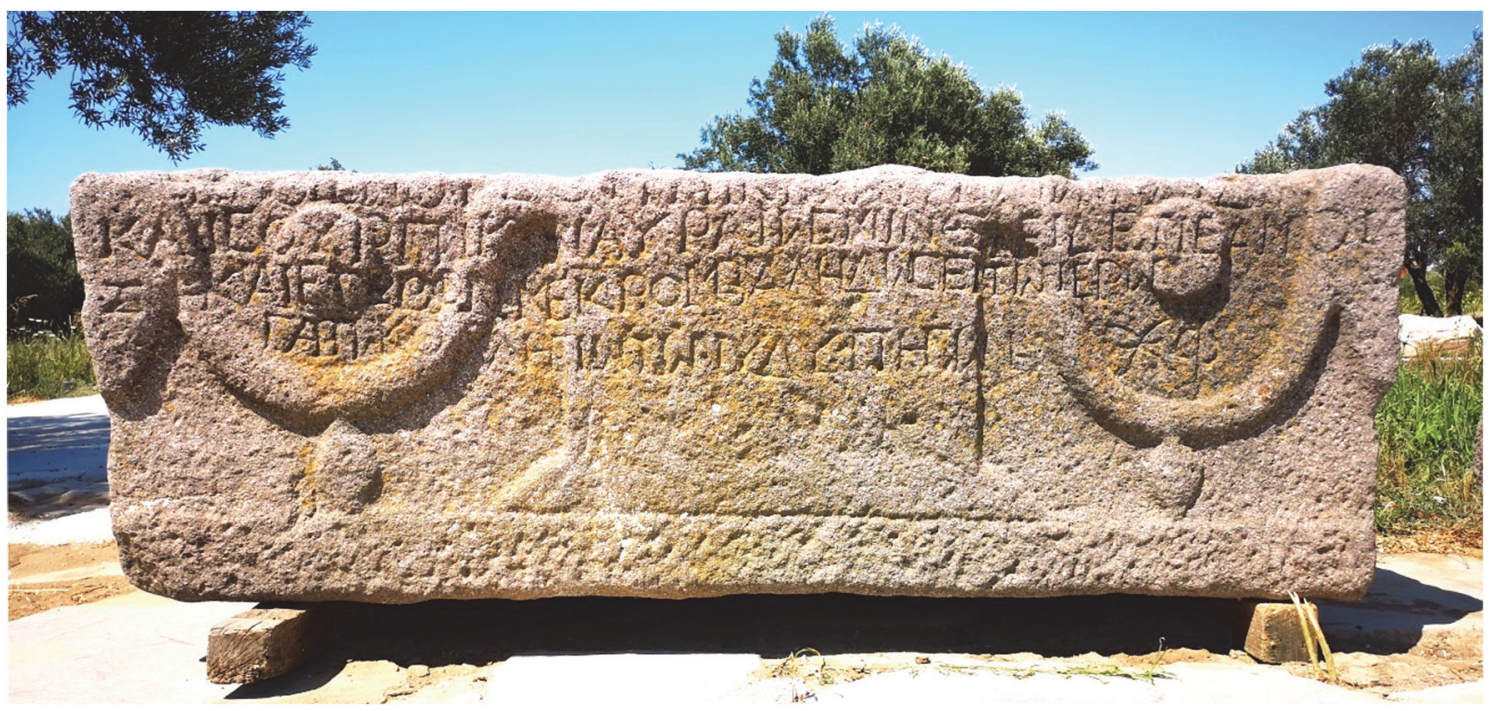

Fig. 1) Inscribed front of the sarcophagus.

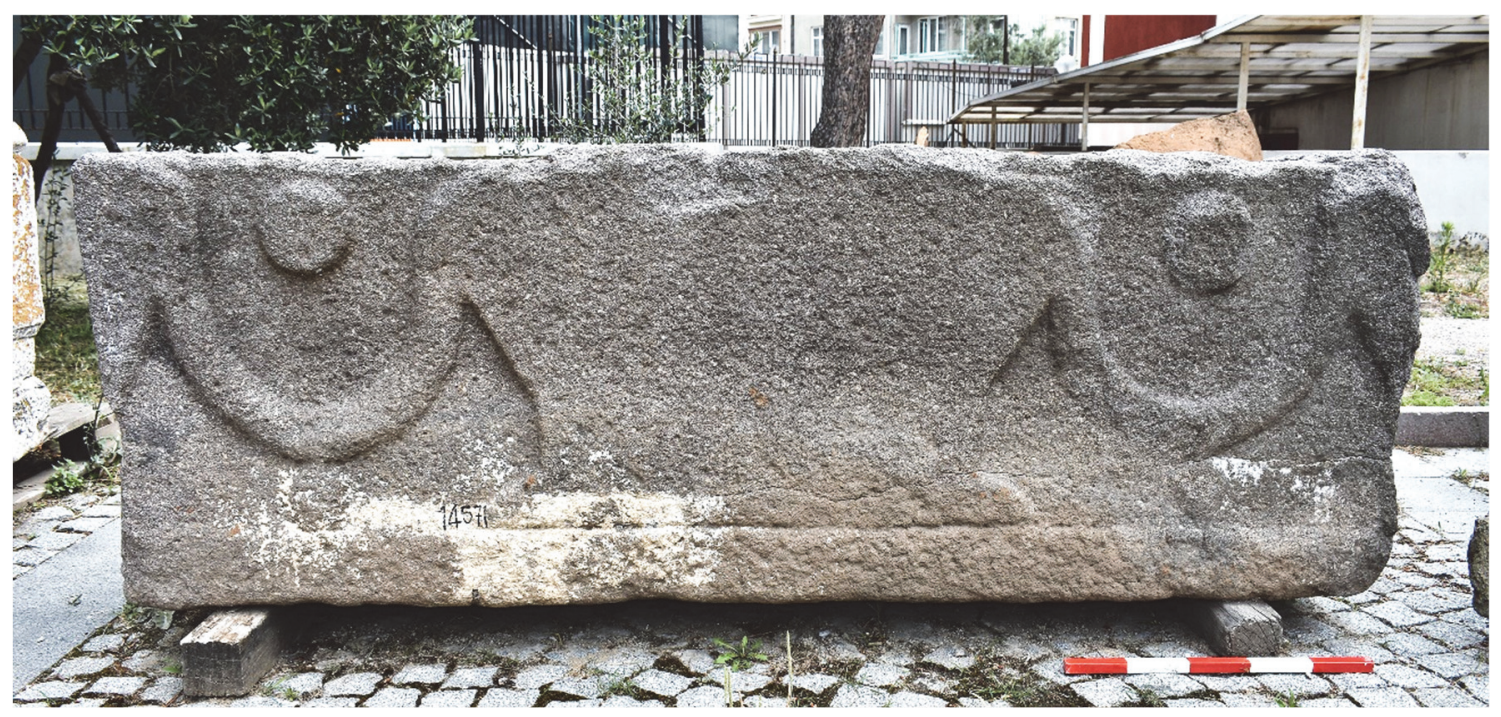

Fig. 2) Back of the sarcophagus. 

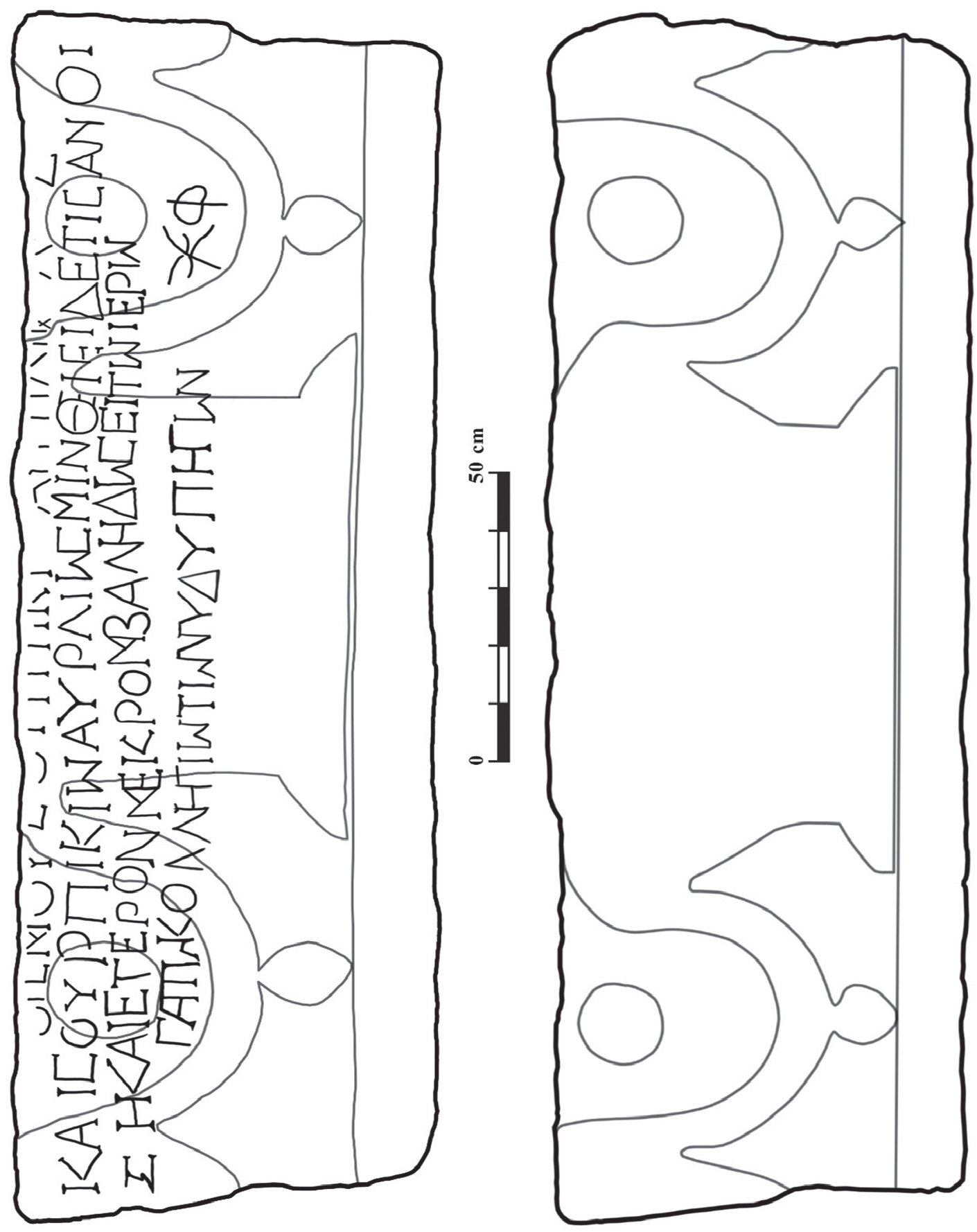

Fig. 3) Drawings of the front and back of the sarcophagus. 

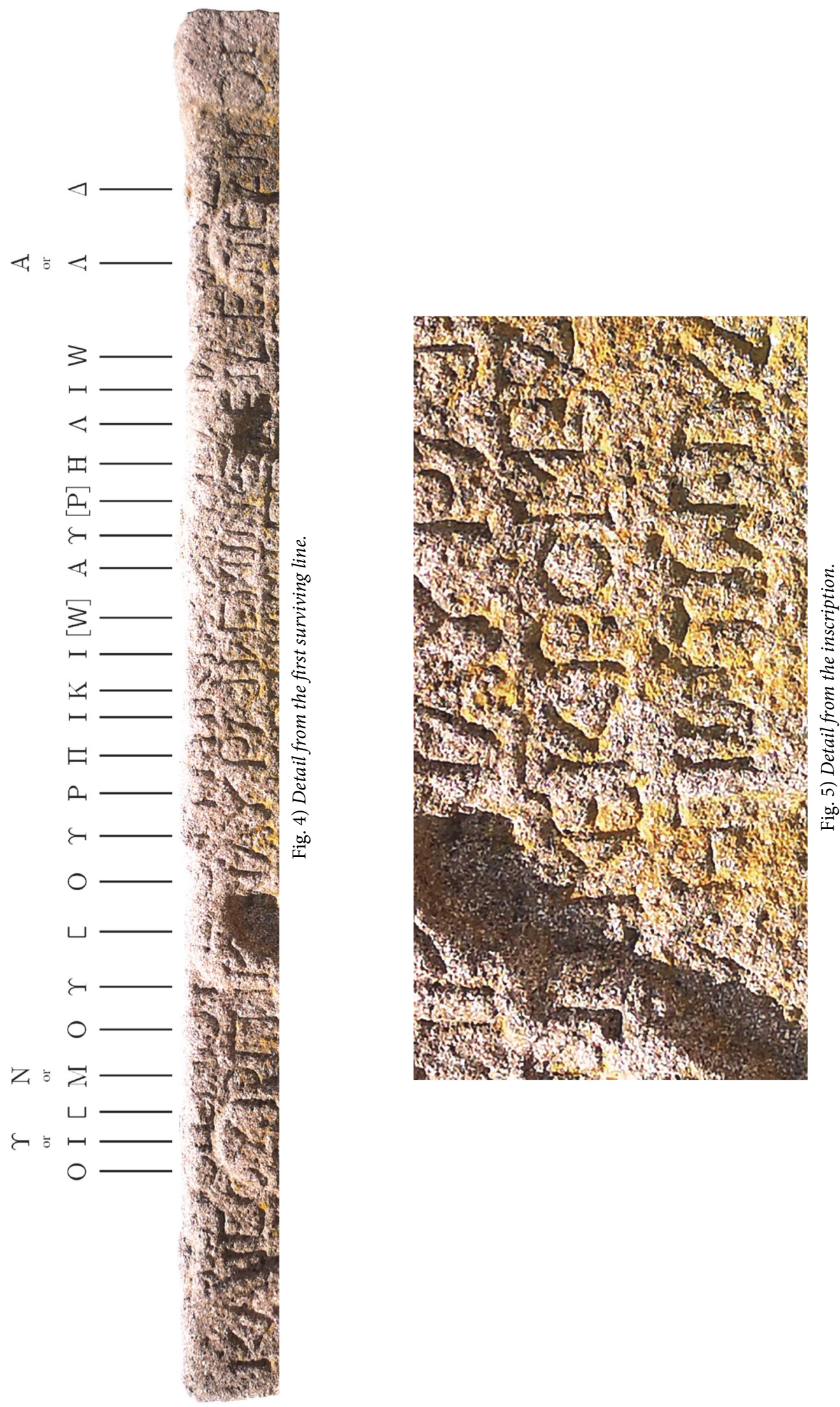